Article

\title{
Comparison of Properties among Dendritic and Hyperbranched Poly(ether ether ketone)s and Linear Poly(ether ketone)s
}

\author{
Atsushi Morikawa \\ Department Biomolecular Functional Engineering, Ibaraki University, 4-12-1, Nakanarusawa, Hitachi, \\ Ibaraki 316-8511, Japan; atsushi.morikawa.reg@vc.ibaraki.ac.jp; Tel.: +81-294-38-5070; Fax: +81-294-38-5078 \\ Academic Editor: Ashok Kakkar \\ Received: 18 December 2015 ; Accepted: 5 February 2016 ; Published: 16 February 2016
}

\begin{abstract}
Poly(ether ether ketone) dendrimers and hyperbranched polymers were prepared from 3,5-dimethoxy-4'-(4-fluorobenzoyl)diphenyl ether and 3,5-dihydroxy-4'-(4-fluorobenzoyl)diphenyl ether through aromatic nucleophilic substitution reactions. 1-(tert-Butyldimethylsiloxy)-3,5-bis(4fluorobenzoyl)benzene was polycondensed with bisphenols, followed by cleavage of the protective group to form linear poly(ether ketone)s having the same hydroxyl groups in the side chains as the chain ends of the dendrimer and hyperbranched polymers. Their properties, such as solubilities, reduced viscosities, and thermal properties, were compared with one another. Similar comparisons were also carried out among the corresponding methoxy group polymers, and the size of the molecules was shown to affect the properties.
\end{abstract}

Keywords: poly(ether ether ketone) dendrimers; hyperbranched polymers; linear poly(ether ketone)s; solubility; reduced viscosities; thermal properties; molecular size

\section{Introduction}

Dendritic macromolecules with branching structures are classified as dendrimers or hyperbranched polymers. Dendrimers are well-defined macromolecules consisting of dendritic units and terminal units that exhibit precise tree-like structures [1] and constructed via step-by-step sequences, requiring isolation and purification [2-12]. Hyperbranched polymers are prepared by one-step polymerization of $\mathrm{AB}_{\mathrm{x}}$-type monomers, resulting in polydispersed macromolecules consisting of dendritic units, linear units, and terminal units that exhibit irregular structures [13-32]. However, the properties of hyperbranched polymers are similar to those of dendrimers $[15,16]$. A key characteristic of these polymers is a branched structure with a large number of chain end groups, to which their low ability of forming intermolecular entanglements is generally ascribed [16]. Hyperbranched polymers and dendrimers have been modified by introduction of functional groups to the chain-end or chain backbone, and a variety of applications, such as encapsulators [33,34], composite materials [35-38], ion-exchange membranes [39], gas separation membrane [40], photoresistors [41], nonlinear optical devices [42,43], diodes [44], cross-linkers [45-47] and heterogeneous catalyst [48-51] have been investigated. In addition, the applications to size-sensitive host [52], subnanomaterial synthesis [53], pH-responsive agents [54], MRI agents [55-57] and drug delivery [58] have been examined due to the precise nanostructures found in dendrimers. The feasibility of these applications was thought to benefit from the presence of a large number of functional sites within the compact space. Linear polymers having functional sites in the side chains are structurally similar, thus the same applications may be possible by using linear polymers having functional sites in the side chains. Therefore, it is important to compare the properties of dendrimers and hyperbranched polymers with those of linear polymers having the same functional groups in the side chains as the end groups of 
dendrimers and hyperbranched polymers in order to examine the functionality derived from the size of the molecules. However, such a comparison has only been reported by Wooly and coworkers in polyesters [15]. The glass transition temperature $T_{\mathrm{g}} \mathrm{s}$ of the dendrimer, the hyperbranched polyester, and the linear polyester were similar, but the dendrimer and the hyperbranched polyester showed higher solubility and special chemical reactivity.

In this study, linear poly(ether ketone)s having hydroxyl groups in the side chain were prepared using hydroxyl-protected 3,5-bis(4-fluorobenzoyl)phenol [14]. The properties of the poly(ether ether ketone) dendrimers, poly(ether ether ketone) hyperbranched polymers, and the linear poly(ether ketone)s, such as solubilities, reduced viscosities, and thermal properties, were compared. The properties of the corresponding polymers having methoxy groups were also compared to evaluate the effect of the terminal group.

\section{Results and Discussion}

\subsection{Poly(ether ether ketone)s Dendrimers}

Poly(ether ether ketone) dendrimers were synthesized using 3,5-dimethoxy-4'-(4-fluorobenzoyl) -diphenyl ether (1) and 1,3,5-tris[ $p$-(3,5-dihydroxyphenoxy)phenyl]benzene (DenG0-OH) as the building block and starting core, respectively, as shown in Scheme 1 [16].

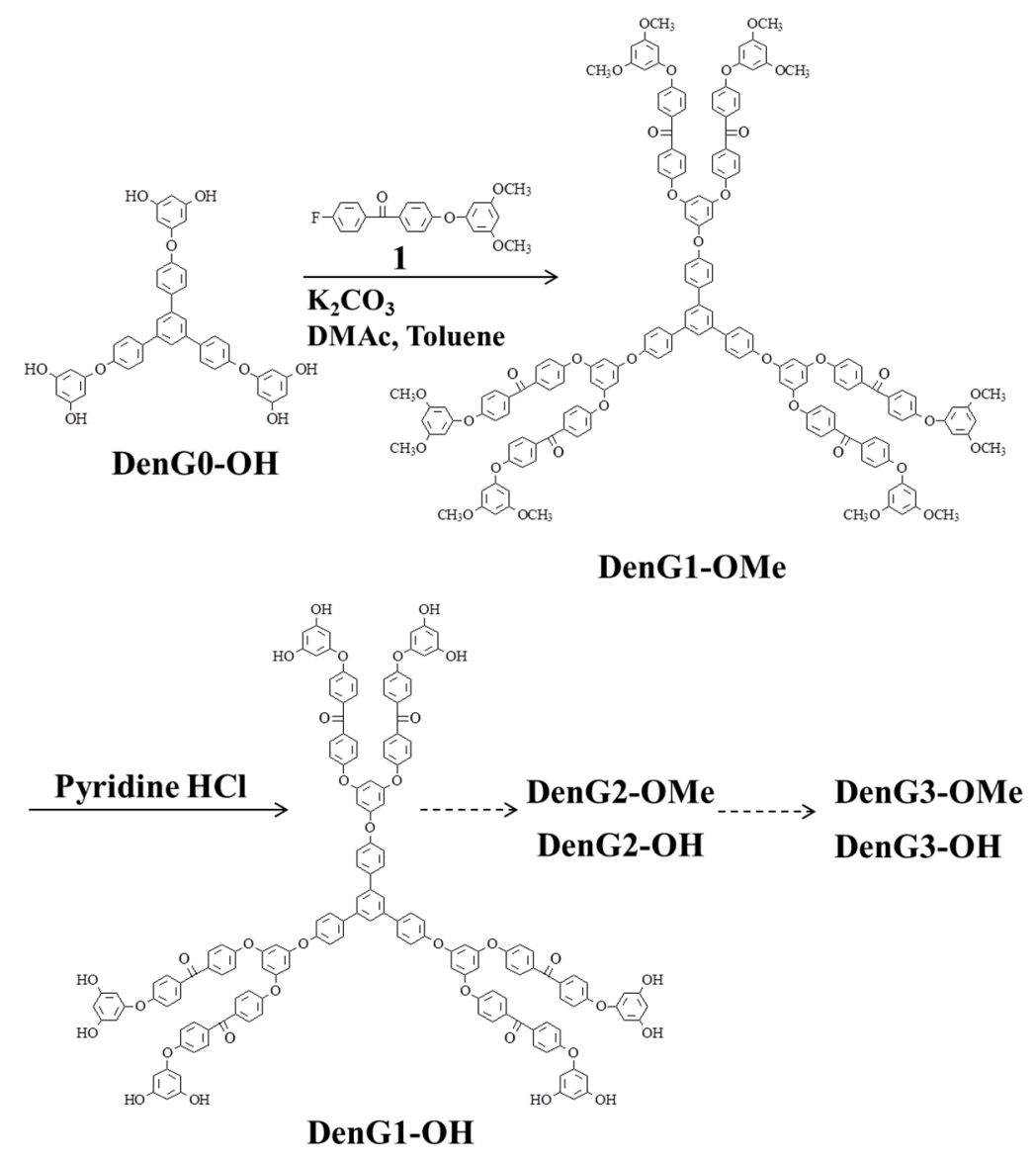

Scheme 1. Synthesis of poly(ether ether ketone) dendrimers.

Reaction of DenG0-OH with $\mathbf{1}$ in the presence of potassium carbonate in $\mathrm{N}, \mathrm{N}$-dimethyl-acetamide (DMAc) and toluene gave the first generation dendrimer (DenG1-OMe) [59]. The water formed during the reaction was removed as an azeotrope. The methoxy groups of DenG1-OMe were converted to hydroxyl terminal first generation (DenG1-OH) by the treatment with pyridine hydrochloride at 
$240{ }^{\circ} \mathrm{C}$. Further reaction of DenG1-OH with 1 gave the second generation dendrimer (DenG2-OMe), and DenG2-OMe was converted to hydroxyl terminal second generation (DenG2-OH). One more repetition of the procedure gave the third generation dendrimer (DenG3-OMe), and hydroxyl terminal third generation (DenG3-OH). All the dendrimers were purified by silica gel column chromatography, and the final isolated yields of DenG1-OMe, DenG2-OMe, and DenG3-OMe were 92\%, 83\%, and 64\%, respectively, and those of DenG1-OH, DenG2-OH, and DenG3-OH were 95\%, 91\%, and 87\%, respectively. The growth and purity were confirmed by gel permeation chromatography (GPC) and MALDI-TOF.

\subsection{Hyperbranched Poly(ether ether ketone)s}

Hyperbranched poly(ether ether ketone)s (Hyper-OH) were synthesized by one-step polycondensation of $\mathrm{AB}_{2}$-type monomer, 3,5-dihydroxy-4'-(4-fluorobenzoyl)diphenylether (2) (Scheme 2) [31]. The polymerization proceeded in the presence of $\mathrm{K}_{2} \mathrm{CO}_{3}$ at $120-165{ }^{\circ} \mathrm{C}$ using a mixture of DMAc and toluene as the solvent [59]. The water formed during the reaction was removed as an azeotrope to promote polymerization. The yield was $88 \%$, and GPC analysis of Hyper-OH gave a number-average molecular weight $(\mathrm{Mn})$ of 5200 and a weight-average molecular weight $(\mathrm{Mw})$ of 20300, which were calibrated against polystyrene standards (Figure 1). With the help of the dendrimers and model compound, ${ }^{1} \mathrm{H}-\mathrm{NMR}$ studies revealed that the degree of branching of $\mathbf{H y p e r - O H}$ was $52 \%$. Hyperbranched poly(ether ether ketone)s (Hyper-OMe) having methoxy groups in the chain ends were prepared by reaction of Hyper-OH with dimethyl sulfate.

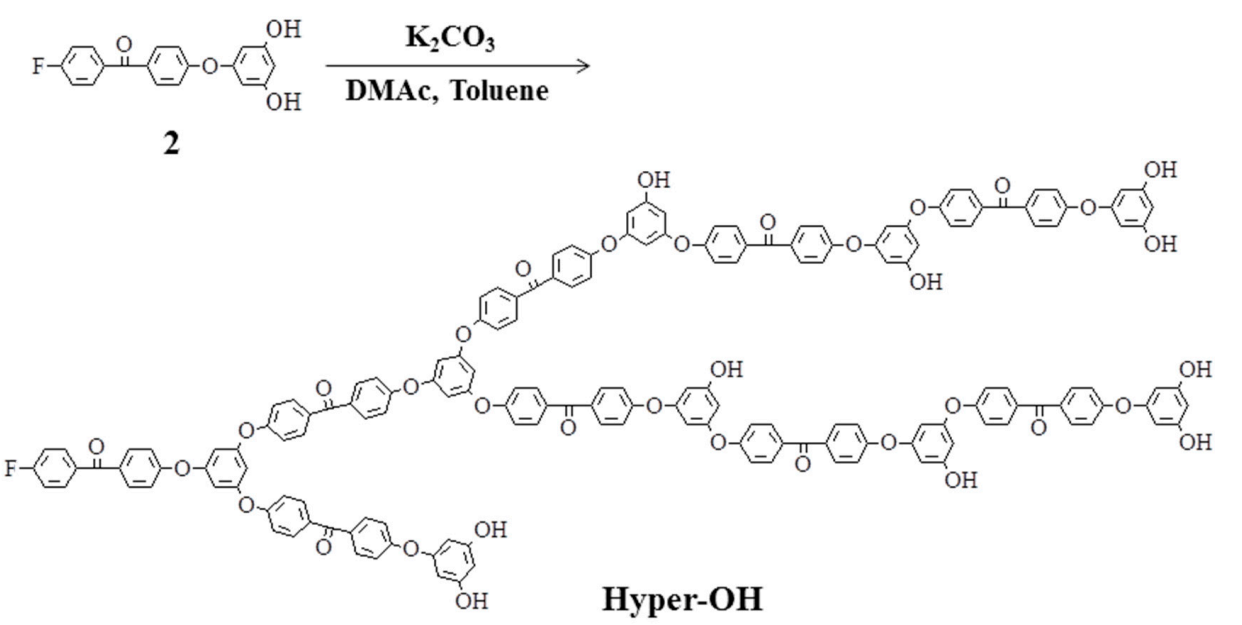

Scheme 2. Synthesis of hyperbranched poly(ether ether ketone).

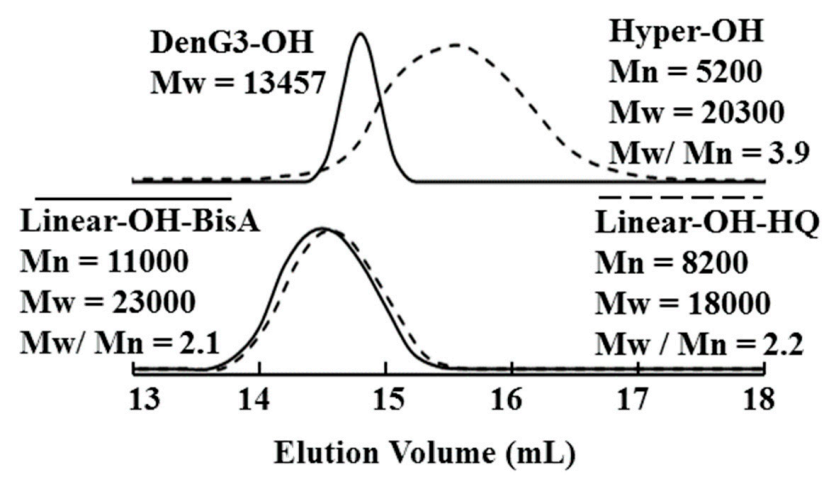

Figure 1. Gel permeation chromatography of DenG3-OH, Hyper-OH, linear-OH-BisA, and linear-OH-HQ. 


\subsection{Linear Poly(ether ketone)s Having Hydroxyl Groups in the Side Chains}

Linear poly(ether ketone)s having hydroxyl groups in the side chains can be synthesized by polycondensation of an AB-type monomer derived by protecting only one hydroxyl group in 2, followed by cleavage of the protective group. Since we could not synthesized one such hydroxyl group protected compound, 3,5-bis(4-fluorobenzoyl)phenol (3) was used for the synthesis of the linear type polymer, which was similar to the linear type poly(ether ether ketone) from 2.

1-(tert-Butyldimethylsilyloxy)-3,5-bis(4-fluorobenzoyl)benzene (4), derived from 3 [60,61], was polycondensed with bisphenols, bisphenol A and hydroquinone, and followed by cleavage of the protective group to form linear poly(ether ketone)s (Scheme 3). Polymerization of 4 with the bisphenols was carried out in the presence of $\mathrm{K}_{2} \mathrm{CO}_{3}$ at $120-165{ }^{\circ} \mathrm{C}$ using a mixture of DMAc and toluene as the solvent [59]. The water formed during the reaction was removed as an azeotrope to promote the polymerization. The polymerizations proceeded homogeneously without gelation. The mixture was poured into water and treated with hydrochloric acid [60,61] to form hydroxyl linear poly(ether ketone)s (Linear-OH-BisA and Linear-OH-HQ) having hydroxyl groups in the side chains. The formations of Linear-OHs were confirmed by appearance of adsorption bands at around $1150 \mathrm{~cm}^{-1}$ characteristic due to ether group and 3600-3200 $\mathrm{cm}^{-1}$ due to hydroxyl group in the IR spectra.

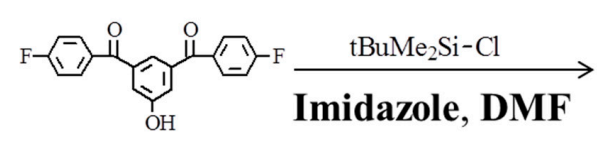

3

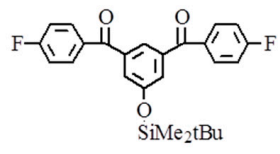

4
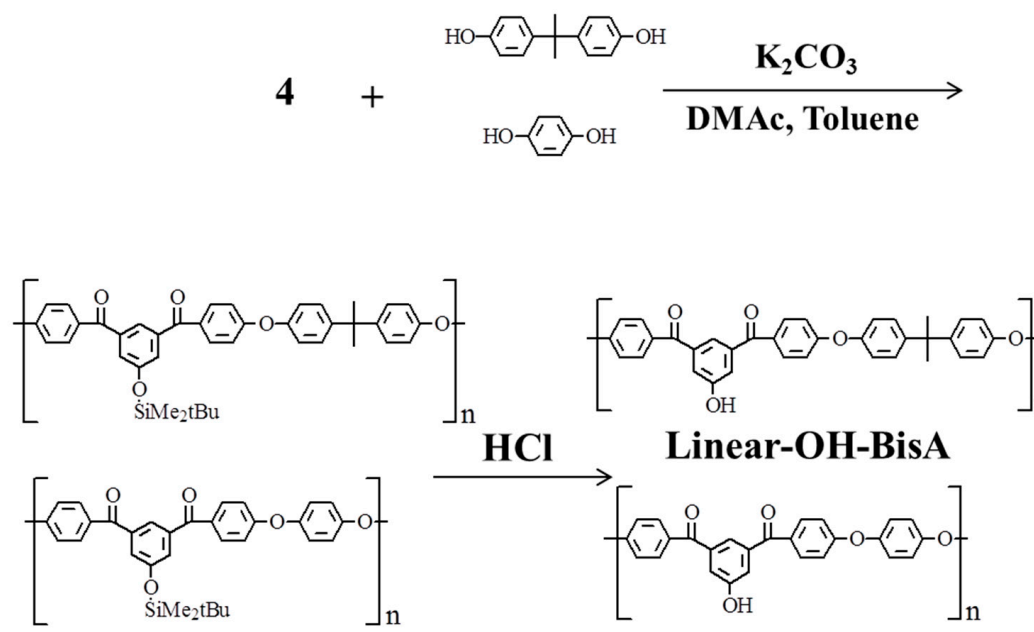

Linear-OH-HQ

Scheme 3. Synthesis of linear poly(ether ketone)s having hydroxyl groups in the side chains.

In the ${ }^{1} \mathrm{H}-\mathrm{NMR}$ spectra (Figure 2) measured for Linear-OH-BisA, the signals assigned to the tert-butyldimethylsilyl group were not observed after treatment with hydrochloric acid, and the deprotection reaction proceeded completely. We also attempted to synthesized 3,5-bis(4-fluoro-benzoyl)anisole (5), the methyl protected compound of 3, for linear poly(ether ketone)s as in the case of the dendrimers. However, while poly(ether ketone) dendrons could be synthesized from 5 [3], the methyl groups could not be completely converted to hydroxyl groups in this synthesis of Linear-OH-BisA and Linear-OH-HQ. The yields of Linear-OH-BisA and Linear-OH-HQ were $87 \%$ and 85\%, respectively. GPC analysis of Linear-OH-BisA gave Mn of 11000 and Mw of 23000, and that of Linear-OH-HQ gave Mn of 8200 and Mw of 18000 (Figure 1). Their molecular weight distributions 
were about 2.0, and smaller than that of Hyper-OH. Molecular weight distribution of Hyperbranched polymer is thought to be higher than that linear polymer due to distribution of DB as well as molecular weight. Linear poly(ether ketone)s (Linear-OMe-BisA and Linear-OMe-HQ) having methoxyl groups in the side chains were prepared by polycondensation of 5 and the bisphenols.

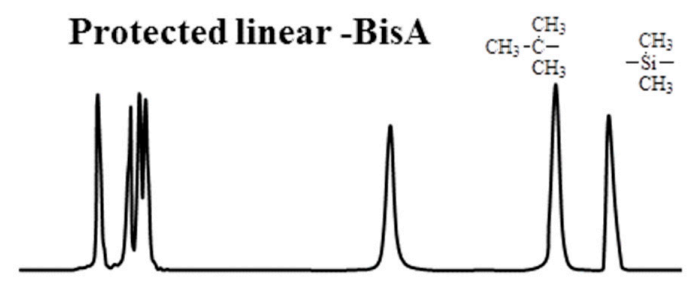

Linear-OH-BisA

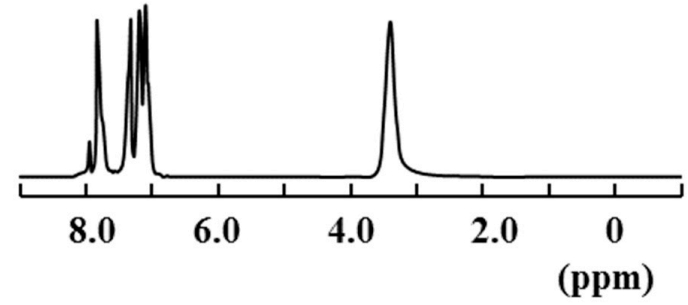

Figure 2. ${ }^{1} \mathrm{H}-\mathrm{NMR}$ spectra of protected Linear-OH-BisA and Linear-OH-BisA.

\subsection{Comparison of Properties}

The solubilities, solution viscosities, and thermal properties of poly(ether ether ketone) dendrimers, hyperbranched poly(ether ether ketone)s, and linear poly(ether ketone)s having hydroxyl groups in the side chains were compared, and the effect of the size of the molecules on the properties was evaluated. Those of DenG3-OMe, Hyper-OMe, Linear-OMe-BisA, and Linear-OMe-HQ were also compared to evaluate effect of terminal group.

Table 1 shows a solubility comparison between DenG3-OMe, Hyper-OMe, Linear-OMe-BisA and Linear-OMe-HQ. They were all soluble in NMP, DMAc, and tetrahydrofuran at room temperature. DenG3-OMe and Hyper-OMe were also soluble in pyridine and non-polar solvents, such as chloroform and toluene, showed broad solubility, but Linear-OMe-BisA and Linear-OMe-HQ were insoluble in pyridine and toluene. Table 2 shows solubilities of DenG3-OH, $\mathbf{H y p e r - O H , ~}$ Linear-OH-BisA and Linear-OH-HQ. They were soluble in pyridine as well as NMP, DMAc, and tetrahydrofuran, and the functional groups in the termini or side chains were reflected in the solubility.

The effect of the size of the molecules on the solubility was observed in alkaline aqueous solution. DenG3-OH was soluble in $1 \mathrm{M}$ aqueous $\mathrm{NaOH}$ solution, Hyper-OH was soluble upon heating, and Linear-OH-BisA and Linear-OH-HQ were insoluble even with heating. DenG3-OH was also soluble in methanol.

Table 1. Solubilities of DenG3-OMe, Hyper-OMe, Linear-OMe-BisA, and Linear-OMe-HQ.

\begin{tabular}{cccccccccc}
\hline $\begin{array}{c}\text { Methoxy Group } \\
\text { Polymer }\end{array}$ & NMP & DMAc & $\mathrm{CHCl}_{3}$ & Pyridine & THF & Toluene & $\mathrm{CH}_{3} \mathrm{OH}$ & $\begin{array}{c}\mathrm{NaOH} \\
\text { Aquation }\end{array}$ \\
\hline DenG3-OMe & ++ & ++ & ++ & ++ & ++ & ++ & -- & -- \\
Hyper-OMe & ++ & ++ & ++ & ++ & ++ & ++ & -- & -- \\
Linear-OMe-BisA & ++ & ++ & ++ & -- & ++ & -- & -- & -- \\
Linear-OMe-HQ & ++ & ++ & -- & -- & ++ & -- & -- & -- \\
\hline
\end{tabular}

Solubility: ++, soluble at room temperature; +, soluble on heating, - -, insoluble. Abbreviation of solvent: NMP, $N$-methyl-2-pyrrolidinone; DMAc, $N, N$-dimethylacetamide; THF, tetrahydrofuran. 
Table 2. Solubilities of DenG3-OH, Hyper-OH, Linear-OH-BisA, and Linear-OH-HQ.

\begin{tabular}{ccccccccc}
\hline $\begin{array}{c}\text { Hydroxy Group } \\
\text { Polymer }\end{array}$ & NMP & DMAc & $\mathrm{CHCl}_{3}$ & Pyridine & THF & Toluene & $\mathrm{CH}_{3} \mathrm{OH}$ & $\begin{array}{c}\mathrm{NaOH} \\
\text { Aquation }\end{array}$ \\
\hline DenG3-OH & ++ & ++ & -- & ++ & ++ & -- & ++ & ++ \\
Hyper-OH & ++ & ++ & -- & ++ & ++ & -- & -- & + \\
Linear-OH-BisA & ++ & ++ & -- & ++ & ++ & -- & -- & -- \\
Linear-OH-HQ & ++ & ++ & -- & ++ & ++ & -- & -- & -- \\
\hline
\end{tabular}

Solubility: ++, soluble at room temperature; +, soluble on heating, - -, insoluble. Abbreviation of solvent: NMP, $N$-methyl-2-pyrrolidinone; DMAc, $N, N$-dimethylacetamide; THF, tetrahydrofuran.

Figure 3 shows the relationship between the reduced viscosities of DenG3-OMe, Hyper-OMe, Linear-OMe-BisA, and Linear-OMe-HQ and the concentration in DMAc. The reduced viscosities of DenG3-OMe, Hyper-OMe, Linear-OMe-BisA, and Linear-OMe-HQ at the concentration of $1.0 \mathrm{~g} / \mathrm{dL}$ were $0.11,0.15,0.43$, and 0.37, respectively. The reduced viscosities of DenG3-OMe and Hyper-OMe were independent of the concentration, and those of Linear-OMe-BisA and Linear-OMe-HQ increased slightly with concentration.

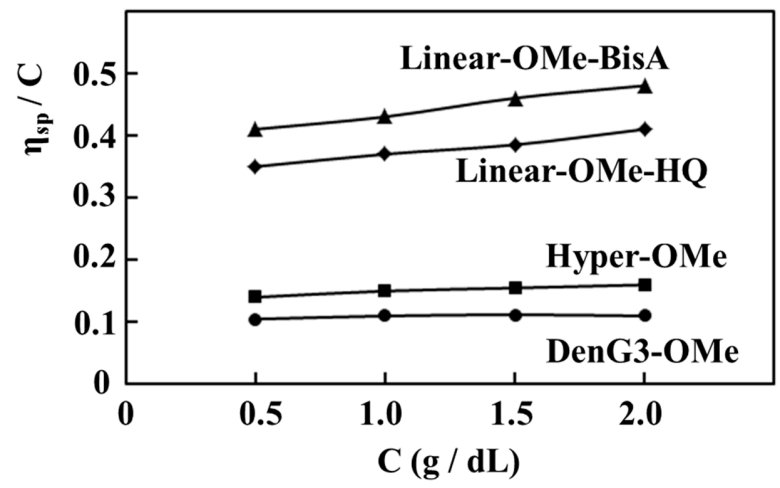

Figure 3. Reduced viscosities of DenG3-OMe, Hyper-OMe, Linear-OMe-BisA, and Linear-OMe-HQ.

Figure 4 shows the relationship between the reduced viscosities of DenG3-OH, Hyper-OH, Linear-OH-bisA and Linear-OH-HQ and the concentration in DMAc. The reduced viscosities of DenG3-OH, Hyper-OH, Linear-OH-BisA, and Linear-OH-HQ at the concentration of $1.0 \mathrm{~g} / \mathrm{dL}$ were $0.11,0.17,0.46$, and 0.39 , respectively, and the GPC results (Figure 1) are reflected in the viscosities. Their higher values suggested a higher degree of interaction with the solvent due to the polarity of the hydroxyl groups. The reduced viscosity of DenG3-OH was independent of the concentration, that of Hyper-OH increased slightly with concentration, and those of Linear-OH-BisA and Linear-OH-HQ increased more significantly than $\mathrm{Hyper-OH}$. The reduced viscosity of the Linear-OHs also increased more than Linear-OMes. The concentration dependence of the reduced viscosity of Hyper-OH slightly reflected the aspect of linear polymer. The length between branching points of Hyper-OH is long due to the benzophenone unit, and this effect may be observed.

Thermal properties were evaluated by differential scanning calorimetry (DSC). Figure 5 shows DSC behaviors of DenG3-OMe, Hyper-OMe, Linear-OMe-BisA, and Linear-OMe-HQ. They seemed to be non-crystalline, and only $T_{\mathrm{g}}$ was observed. $T_{\mathrm{g}} \mathrm{s}$ of DenG3-OMe, Hyper-OMe, Linear-OMe-BisA, and Linear-OMe-HQ were 101, 160, 105 and $144{ }^{\circ} \mathrm{C}$, respectively, and the order of increasing $T_{\mathrm{g}}$ values was DenG3-OMe $<$ Linear-OMe-BisA $<$ Linear-OMe-HQ $<$ Hyper-OMe. The structure of the dendrimer molecule was near spherical due to perfect branching and compact structures, but that of the hyperbranched molecule was not near spherical due to moderate DB $(52 \%)$, and the surface area of the hyperbranched molecule was larger. The interaction between the hyperbranched molecules was thought to be larger due to the larger surface area. $T_{\mathrm{g}}$ of hyperbranched molecules is thought to be higher than linear polymers due to both branching and the interaction among molecules. 


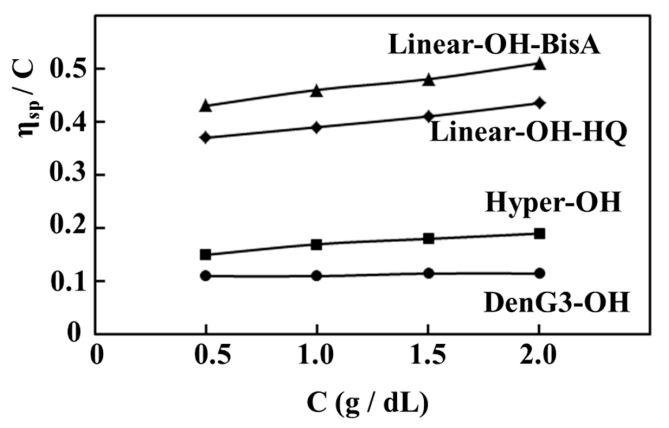

Figure 4. Reduced viscosities of DenG3-OH, Hyper-OH, Linear-OH-BisA and Linear-OH-HQ.

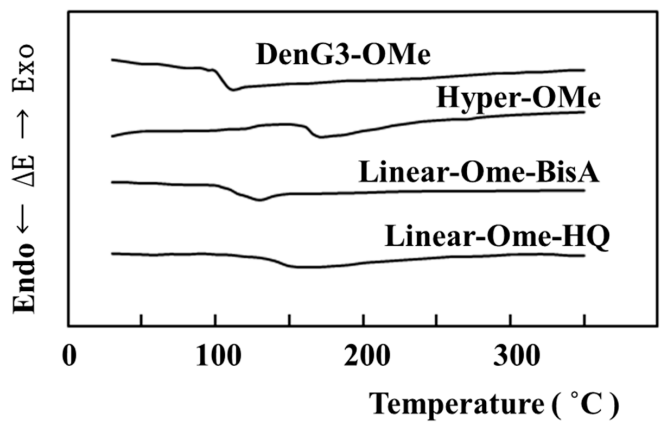

Figure 5. DSC curves of DenG3-OMe, Hyper-OMe, Linear-OMe-BisA, and Linear-OMe-HQ.

Figure 6 shows DSC behaviors of DenG3-OH, Hyper-OH, Linear-OH-BisA, and Linear-OH-HQ. DenG3-OH and Hyper-OH also seemed to be non-crystalline, and $T_{\mathrm{g}} \mathrm{s}$ were observed at 144 and $190^{\circ} \mathrm{C}$, respectively. Linear-OH-BisA exhibited $T_{\mathrm{g}}$ at $145^{\circ} \mathrm{C}$ followed by exothermic crystallization at $250-305{ }^{\circ} \mathrm{C}$, and Linear-OH-HQ exhibited $T_{\mathrm{g}}$ at $155^{\circ} \mathrm{C}$ followed by exothermic crystallization at $280-340{ }^{\circ} \mathrm{C}$. Linear-OH-BisA exhibited an endothermic melting peak at $305-320{ }^{\circ} \mathrm{C}$. $T_{\mathrm{gs}}$ of Hyper-OMe and Hyper-OH were also much higher than the corresponding dendrimers and linear polymers, and in contrast to the polyesters having hydroxyl groups [15]. $T_{\mathrm{g}} \mathrm{s}$ of hyperbranched and dendritic polyesters having hydroxyl groups in the chain ends were almost the same as the $T_{\mathrm{g}}$ of the linear polyester having hydroxyl groups in the side chains. DenG3-OH and Hyper-OH did not crystallize, but Linear-OH-BisA and Linear-OH-HQ crystallized. Dendritic polymers could not be crystallized due to their branching structures, and attachment of crystalline molecules to the chain ends as a molecular scaffold was reported to be necessary for the crystallization of hyperbranched polymers [18,24]. Since the chains of Linear-OH-BisA and Linear-OH-HQ without branching were flexible, the crystallizations were thought to be induced due to hydrogen bonding by the hydroxyl groups.

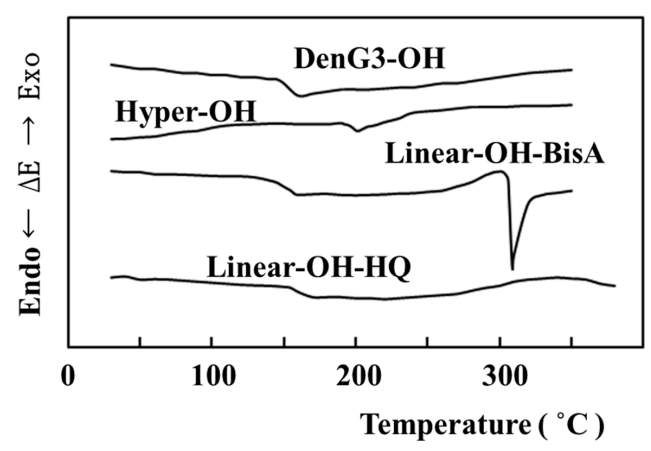

Figure 6. DSC curves of DenG3-OH, Hyper-OH, Linear-OH-BisA, and Linear-OH-HQ. 


\section{Experimental Section}

\subsection{General Information}

${ }^{1} \mathrm{H}$ - and ${ }^{13} \mathrm{C}-\mathrm{NMR}$ spectra were recorded on a JNM-GSX400 FT-NMR spectrometer (JEOL, Akishima, Japan) and IR spectra were recorded on a IR 435 spectrophotometer (Shimadzu, Kyoto, Japan). GPC was carried out on a PL gel $5 \mu$ MIXED-C analytical column (Polymer Laboratories, Tokyo, Japan) with tetrahydrofuran as the eluent. Reduced viscosity was measured at various concentrations using an Ubbelohde-type capillary viscometer (Shibata, Sohka, Japan) in DMAc at $30^{\circ} \mathrm{C}$. MALDI-TOF MS were measured on a Shimadzu/Kratos Kompact MALDI II (Shimadzu) equipped with a 337 $\mathrm{nm}$ nitrogen laser. DSC was performed with a Shimadzu DSC-60 (Shimadzu), instrument and measurements were made at a heating rate of $10{ }^{\circ} \mathrm{C} \mathrm{min}-1$ in nitrogen. The results from first scan were displayed in Figures 5 and 6.

\subsection{Conventional Synthesis}

\subsubsection{Third Generation Dendrimer (DenG3-OMe)}

In a flask, a mixture of $\mathbf{1}(7.05 \mathrm{~g}, 20 \mathrm{mmol})$, DenG0-OH $(1.70 \mathrm{~g}, 2.5 \mathrm{mmol})$, potassium carbonate $(2.76 \mathrm{~g}, 20 \mathrm{mmol})$, toluene $(30 \mathrm{~mL})$, and DMAc $(60 \mathrm{~mL})$ was stirred at $130^{\circ} \mathrm{C}$ for $1 \mathrm{~h}$. The temperature was raised to $160{ }^{\circ} \mathrm{C}$ and water formed during the reaction was removed as an azeotrope with toluene. The reaction mixture was stirred at this temperature for $1.5 \mathrm{~h}$. After the reaction was complete, the mixture was cooled to about $80^{\circ} \mathrm{C}$, and the solvent was evaporated under reduced pressure of 15-20 torr. The residue was washed with water $(300 \mathrm{~mL})$ and extracted twice with methylene chloride $(200 \mathrm{~mL})$. After the combined extract was dried over anhydrous magnesium sulfate, the solvent was evaporated. Pure DenG1-OMe was obtained by silica gel column chromatography beginning with methylene chloride as the eluent and gradually changing to methylene chloride and ethyl acetate (20:1), yield: $92 \%$.

DenG1-OMe (5.35 g, 2 mmol) was heated together with pyridine hydrochloride (50 g) at reflux temperature for about $30 \mathrm{~min}$. After the reaction mixture was homogeneous, it was poured into water $(1000 \mathrm{~mL})$, and extracted twice with ethyl acetate $(100 \mathrm{~mL})$. The combined extract was dried over anhydrous magnesium sulfate. After evaporation of the solvent, pure DenG1-OH was obtained by silica gel column chromatography by methylene chloride and ethyl acetate (1:1). Yield: 95\%.

DenG2-OMe was prepared by the same procedure as that for synthesis of DenG1-OMe using DenG1-OH (2.50 g, $1 \mathrm{mmol}), 1(6.34 \mathrm{~g}, 18 \mathrm{mmol})$, potassium carbonate $(2.49 \mathrm{~g}, 18 \mathrm{mmol})$, toluene (23 mL), and DMAc (60 mL). Pure DenG2-OMe was obtained by silica gel column chromatography beginning with methylene chloride and ethyl acetate (25:1) as the eluent and gradually changing to methylene chloride and ethyl acetate (15:1), yield: $83 \%$.

DenG2-OH was prepared by the same procedure as that for synthesis of DenG1-OH using DenG2-OMe ( $4.54 \mathrm{~g}, 0.7 \mathrm{mmol})$, and pyridine hydrochloride (60 g). Pure DenG2-OH was obtained by silica gel column by methylene chloride and ethyl acetate (3:7), yield: $91 \%$.

DenG3-OMe was prepared by the same procedure as that for synthesis of DenG1-OMe using DenG2-OH (1.85 g, $0.3 \mathrm{mmol}), 1(3.81 \mathrm{~g}, 10.8 \mathrm{mmol})$, potassium carbonate $(1.49 \mathrm{~g}, 10.8 \mathrm{mmol})$, 15 toluene $(15 \mathrm{~mL})$, and DMAc $(30 \mathrm{~mL})$. Pure DenG3-OMe was obtained by silica gel column chromatography beginning with methylene chloride and ethyl acetate (20:1) as the eluent and gradually changing to methylene chloride and ethyl acetate (13:1). Yield 62\%; white powder; Elemental Analysis: $\mathrm{C}_{888} \mathrm{H}_{630} \mathrm{O}_{117}$; Calculated $\% \mathrm{C}=75.47, \% \mathrm{H}=4.49$. Observed. $\% \mathrm{C}=75.35, \% \mathrm{H}=4.41$. FT-IR $/$ ATR $v\left(\mathrm{~cm}^{-1}\right): 2940,1655,1590,1225$, and $1160 \mathrm{~cm}^{-1}$; TOF-MS: $14133, \mathrm{C}_{888} \mathrm{H}_{630} \mathrm{O}_{177}(\mathrm{Mw}=14131) ;{ }^{1} \mathrm{H}-\mathrm{NMR}$ $\left(\mathrm{CDCl}_{3}\right)$ ppm: 7.83-7.47 (m,168H, Ar), $7.68(\mathrm{~s}, 3 \mathrm{H}, \mathrm{Ar}), 7.65(\mathrm{~d}, 6 \mathrm{H}, J=8.8 \mathrm{~Hz}, \mathrm{Ar}), 7.15(\mathrm{~d}, 6 \mathrm{H}, J=8.8 \mathrm{~Hz}$, Ar), 7.10-7.06 (m,120H, Ar), $7.04(\mathrm{~d}, 48 \mathrm{H}, J=8.8 \mathrm{~Hz}, \mathrm{Ar}), 6.58(\mathrm{~m}, 4 \mathrm{H}, \mathrm{Ar}), 6.48(\mathrm{t}, 3 \mathrm{H}, J=2.2 \mathrm{~Hz}, \mathrm{Ar})$, $6.28(\mathrm{t}, 24 \mathrm{H}, J=2.2 \mathrm{~Hz}, \mathrm{Ar}), 6.22(\mathrm{~d}, 48 \mathrm{H}, J=2.2 \mathrm{~Hz}, \mathrm{Ar}), 3.75\left(\mathrm{~s}, 144 \mathrm{H},-\mathrm{CH}_{3}\right) ;{ }^{13} \mathrm{C}-\mathrm{NMR}\left(\mathrm{CDCl}_{3}\right)$ ppm: 193.9 (C=O), 193.9 (C=O), 193.8 (C=O), 161.9 (Ar), 161.1 (Ar), 160.1 (Ar), 160.1 (Ar), 160.0 (Ar), 
159.9 (Ar), $159.9(\mathrm{Ar}), 159.8(\mathrm{Ar}), 158.5(\mathrm{Ar}), 158.5(\mathrm{Ar}), 158.5(\mathrm{Ar}), 158.2(\mathrm{Ar}), 157.5(\mathrm{Ar}), 155.6(\mathrm{Ar})$, 141.6 (Ar), 137.2 (Ar), 133.5 (Ar), 133.3 (Ar), $133.2(\mathrm{Ar}), 133.2(\mathrm{Ar}), 133.0(\mathrm{Ar}), 132.3(\mathrm{Ar}), 132.2(\mathrm{Ar})$, 132.2 (Ar), $132.1(\mathrm{Ar}), 131.9(\mathrm{Ar}), 128.9(\mathrm{Ar}), 124.7(\mathrm{Ar}), 120.0(\mathrm{Ar}), 118.5(\mathrm{Ar}), 118.2(\mathrm{Ar}), 118.1(\mathrm{Ar})$, 117.6 (Ar), 106.3 (Ar), 106.3 (Ar), 106.2 (Ar), 105.5 (Ar), 105.3 (Ar), 98.6 (Ar), $96.8(\mathrm{Ar})$, 55.5(- $\left.\mathrm{CH}_{3}\right)$.

\subsubsection{Hydroxyl Terminal Third Generation (DenG3-OH)}

DenG3-OH was prepared by the same procedure as that used for synthesis of DenG1-OH using DenG3-OMe (2.11 g, $0.15 \mathrm{mmol})$, and pyridine hydrochloride $(80 \mathrm{~g})$. Pure DenG3-OH was obtained by silica gel column by methylene chloride and ethyl acetate (3:7). Yield $87 \%$; white powder; Elemental Analysis: $\mathrm{C}_{840} \mathrm{H}_{534} \mathrm{O}_{117}$; Calculated $\% \mathrm{C}=74.96, \% \mathrm{H}=4.00$. Observed. $\% \mathrm{C}=75.01, \% \mathrm{H}=4.03$. FT-IR/ATR $v\left(\mathrm{~cm}^{-1}\right)$ : 3400-3000, 1650, 1590, 1227, and $1162 \mathrm{~cm}^{-1}$; TOF-MS: 13,459, $\mathrm{C}_{840} \mathrm{H}_{534} \mathrm{O}_{117}$ $(\mathrm{Mw}=13,457) ;{ }^{1} \mathrm{H}-\mathrm{NMR}$ (DMSO- $\left.d_{6}\right)$ ppm: 9.02(s, 48H, -OH), 7.77-7.65 (m,177H, Ar), 7.20-7.09 $(\mathrm{m}, 126 \mathrm{H}, \mathrm{Ar}), 7.05(\mathrm{~d}, 48 \mathrm{H}, J=8.8 \mathrm{~Hz}, \mathrm{Ar}), 6.63(\mathrm{~m}, 36 \mathrm{H}, \mathrm{Ar}), 6.61(\mathrm{~m}, 18 \mathrm{H}, \mathrm{Ar}), 6.55(\mathrm{~m}, 9 \mathrm{H}, \mathrm{Ar})$, $6.08(\mathrm{t}, 24 \mathrm{H}, J=2.2 \mathrm{~Hz}, \mathrm{Ar}), 5.93(\mathrm{~d}, 48 \mathrm{H}, J=2.2 \mathrm{~Hz}, \mathrm{Ar}) ;{ }^{13} \mathrm{C}-\mathrm{NMR}$ (DMSO-d $\left.d_{6}\right)$ ppm: $192.6(\mathrm{C}=\mathrm{O})$, 192.5 (C=O), $192.5(\mathrm{C}=\mathrm{O}), 160.2(\mathrm{Ar}), 159.4(\mathrm{Ar}), 159.1(\mathrm{Ar}), 159.0(\mathrm{Ar}), 159.0(\mathrm{Ar}), 158.9(\mathrm{Ar}), 158.9(\mathrm{Ar})$, 158.7 (Ar), 157.7 (Ar), 157.7 (Ar), 157.6 (Ar), 157.5 (Ar), 157.5 (Ar), 155.6 (Ar), $154.9(\mathrm{Ar}), 140.4(\mathrm{Ar})$, 135.8 (Ar), 132.7 (Ar), 132.4 (Ar), 132.4 (Ar), 132.0 (Ar), 131.4 (Ar), 131.4 (Ar), 131.2 (Ar), $128.3(\mathrm{Ar})$, 124.0 (Ar), 119.2 (Ar), 117.8 (Ar), 117.7 (Ar), 117.2 (Ar), 117.1 (Ar), 105.8 (Ar), $105.7(\mathrm{Ar}), 105.7$ (Ar), 105.6 (Ar), 104.7 (Ar), 104.5 (Ar), 98.9 (Ar), 97.7 (Ar).

\subsubsection{Hyperbranched Poly(ether ether ketone) (Hyper-OH)}

A mixture of $2(1.62 \mathrm{~g}, 5 \mathrm{mmol})$, potassium carbonate $(0.373 \mathrm{~g}, 2.7 \mathrm{mmol})$, toluene $(10 \mathrm{~mL})$ and $\mathrm{N}, \mathrm{N}$-dimethylacetamide (DMAc) $(20 \mathrm{~mL})$ was stirred in a flask at $120^{\circ} \mathrm{C}$. The temperature was then raised from $120{ }^{\circ} \mathrm{C}$ to $165{ }^{\circ} \mathrm{C}$, to remove water formed during the reaction as an azeotrope with toluene. The reaction mixture was stirred at this temperature for $6 \mathrm{~h}$. The polymerization proceeded homogeneously. After the reaction was completed, the mixture was cooled to room temperature and poured into $300 \mathrm{~mL}$ of methanol. The precipitated polymer was collected by filtration, washed thoroughly with water and methanol, and dried under vacuum. Yield $88 \%$; white powder; Elemental Analysis: $\mathrm{C}_{19} \mathrm{H}_{12} \mathrm{O}_{4} ;$ Calculated $\% \mathrm{C}=74.99, \% \mathrm{H}=3.97$. Observed. $\% \mathrm{C}=74.52, \% \mathrm{H}=3.64$. FT-IR/ATR $v\left(\mathrm{~cm}^{-1}\right): 3400-3000$, and $1240 \mathrm{~cm}^{-1} ;{ }^{1} \mathrm{H}-\mathrm{NMR}$ (DMSO- $\left.d_{6}\right)$ ppm: 7.86-7.58 $(\mathrm{m}, 4 \mathrm{H}, \mathrm{Ar}), 7.30-7.00(\mathrm{~m}, 4 \mathrm{H}$, Ar), 6.72-6.64 (m, 0.51H, dendritic Ar), 6.36-6.31 (m, 1.03H, linear Ar), 6.31-6.24 (m, 0.51H, linear Ar), 6.08-6.04 (m, 0.32H, terminal Ar), 5.96-5.90 (m, 0.64H, terminal Ar), $5.93(\mathrm{~d}, 48 \mathrm{H}, J=2.2 \mathrm{~Hz}, \mathrm{Ar})$.

\subsubsection{Hyperbranched Poly(ether ether ketone) (Hyper-OMe)}

A mixture of $2(1.62 \mathrm{~g}, 5 \mathrm{mmol})$, potassium carbonate $(0.373 \mathrm{~g}, 2.7 \mathrm{mmol})$, toluene $(10 \mathrm{~mL})$ and DMAc $(20 \mathrm{~mL})$ was stirred in a flask at $120^{\circ} \mathrm{C}$. The temperature was then raised from $120^{\circ} \mathrm{C}$ to $165^{\circ} \mathrm{C}$ to remove water formed during the reaction as an azeotrope with toluene, and the reaction mixture was stirred at this temperature for $6 \mathrm{~h}$. After the reaction mixture was cooled to room temperature, methyl sulfate $(0.38 \mathrm{~g}, 3 \mathrm{mmol})$ and potassium carbonate $(0.42 \mathrm{~g}, 3 \mathrm{mmol})$ were added. The mixture was stirred at $80^{\circ} \mathrm{C}$ for another $6 \mathrm{~h}$, cooled to room temperature, and poured into $300 \mathrm{~mL}$ of methanol. The precipitated polymer was collected by filtration, washed thoroughly with water and methanol, and dried under vacuum. Yield: $85 \%$; white powder; Elemental Analysis: $\mathrm{C}_{20} \mathrm{H}_{14} \mathrm{O}_{4}$; Calculated $\% \mathrm{C}=75.46, \% \mathrm{H}=4.43$. Observed. $\% \mathrm{C}=75.05, \% \mathrm{H}=4.23$. FT-IR $/$ ATR $v\left(\mathrm{~cm}^{-1}\right): 2945,1650$ and $1240 \mathrm{~cm}^{-1} ;{ }^{1} \mathrm{H}-\mathrm{NMR}$ (DMSO- $d_{6}$ ) ppm: 7.86-7.58 (m,4H, Ar), 7.30-7.00 (m, 4H, Ar), 6.72-6.64 (m, 0.52H, dendritic Ar), 6.36-6.31 (m, 1.00H, linear Ar), 6.31-6.24 (m, 0.50H, linear Ar), 6.07-6.01 (m, 0.33H, terminal Ar), $6.00-5.93\left(\mathrm{~m}, 0.65 \mathrm{H}\right.$, terminal Ar), 3.81-3.75 (s, 3H, $\left.-\mathrm{CH}_{3}\right)$.

\subsubsection{1-(tert-Butyldimethylsilyloxy)-3,5-bis(4-fluorobenzoyl)benzene (4)}

A solution of tert-butyldimethylchlorosilane $(4.97 \mathrm{~g}, 33 \mathrm{~mol})$ in $\mathrm{N}, \mathrm{N}$-dimethylformamide (DMF) $(20 \mathrm{~mL})$ was added dropwise to a solution of $3(10.15 \mathrm{~g}, 30 \mathrm{mmol})$ and imidazole $(2.25 \mathrm{~g}, 33 \mathrm{mmol})$ in 
DMF $(40 \mathrm{~mL})$ at $0{ }^{\circ} \mathrm{C}$. After stirring at $25^{\circ} \mathrm{C}$ for $3 \mathrm{~h}$, the precipitated imidazole salt was removed by filtration, and the solvent was evaporated. The residue was distilled under reduced pressure (glass tube oven) to pure 1-(tert-butyldimethylsilyloxy)-3,5-bis(4-fluorobenzoyl)benzene. Yield 72\%; transparent oil; Bp: $240{ }^{\circ} \mathrm{C}(1.0 \mathrm{mmHg})$; Elemental Analysis: $\mathrm{C}_{26} \mathrm{H}_{26} \mathrm{~F}_{2} \mathrm{O}_{3} \mathrm{Si}$; Calculated \%C = 69.00, \% $\mathrm{H}=5.79$. Observed. $\% \mathrm{C}=68.72, \% \mathrm{H}=5.61$. FT-IR/ATR $v\left(\mathrm{~cm}^{-1}\right): 3060,2930,1650,1600,1230$, and $1150 \mathrm{~cm}^{-1}$; TOF-MS: 451, $\mathrm{C}_{26} \mathrm{H}_{26} \mathrm{~F}_{2} \mathrm{O}_{3} \mathrm{Si}(\mathrm{Mw}=452.6) ;{ }^{1} \mathrm{H}-\mathrm{NMR}\left(\mathrm{CDCl}_{3}\right) \mathrm{ppm}: 7.88(\mathrm{~m}, 4 \mathrm{H}, \mathrm{Ar}), 7.65(\mathrm{t}, 1 \mathrm{H}$, $J=8.8 \mathrm{~Hz}, \mathrm{Ar}), 7.54(\mathrm{~d}, 2 \mathrm{H}, J=8.8 \mathrm{~Hz}, \mathrm{Ar}), 7.17(\mathrm{~m}, 4 \mathrm{H}, \mathrm{Ar}), 0.96\left(\mathrm{~s}, 9 \mathrm{H},-\mathrm{CH}_{3}\right), 0.09\left(\mathrm{~s}, 6 \mathrm{H},-\mathrm{CH}_{3}\right)$; ${ }^{13} \mathrm{C}-\mathrm{NMR}\left(\mathrm{CDCl}_{3}\right)$ ppm: $194.0(\mathrm{C}=\mathrm{O}), 160.5(\mathrm{~d}, \mathrm{~J}=254 \mathrm{~Hz})(\mathrm{Ar}), 159.5(\mathrm{Ar}), 139.4(\mathrm{Ar}), 133.0(\mathrm{~d}, \mathrm{~J}=3 \mathrm{~Hz})$ (Ar), 132.5 (d, $J=10 \mathrm{~Hz}$ (Ar), $123.7(\mathrm{Ar}), 118.5(\mathrm{Ar}), 116.0(\mathrm{~d}, J=22 \mathrm{~Hz})(\mathrm{Ar}), 34.6\left(-\mathrm{CH}_{3}\right), 32.8\left(-\mathrm{CH}_{3}\right)$.

\subsubsection{Linear poly(ether ketone) Having Hydroxyl Groups in the Side Chains (Linear-OH-BisA)}

A mixture of 4 (1.13 g, $2.5 \mathrm{mmol})$, bisphenol A (0.571 g, $2.5 \mathrm{mmol})$, potassium carbonate $(0.345 \mathrm{~g}$, $2.5 \mathrm{mmol})$, toluene $(10 \mathrm{~mL})$ and DMAc $(20 \mathrm{~mL})$ was stirred in a flask at $120^{\circ} \mathrm{C}$. The temperature was then raised from $120{ }^{\circ} \mathrm{C}$ to $165{ }^{\circ} \mathrm{C}$, to remove water formed during the reaction as an azeotrope in toluene. The reaction mixture was stirred at this temperature for $6 \mathrm{~h}$. The polymerization proceeded homogeneously. The mixture was cooled to room temperature, and poured into water (300 mL). The precipitated polymer was collected by filtration, and dried under vacuum. Yield: 95\%; white powder; FT-IR/ATR $v\left(\mathrm{~cm}^{-1}\right)$ : 3060, 2930, 1650, 1600, 1230, and $1150 \mathrm{~cm}^{-1}$; ${ }^{1} \mathrm{H}-\mathrm{NMR}$ (DMSO- $\left.d_{6}\right)$ ppm: 8.10-7.70 (m,3H, Ar), 7.50-7.30 (m, 4H, Ar), 7.30-6.96 (m, 12H, Ar), 3.4 (s, 6H,-CH $), 0.90$ (s, 9H, $\left.-\mathrm{CH}_{3}\right), 0.15\left(\mathrm{~s}, 6 \mathrm{H},-\mathrm{CH}_{3}\right)$. Hydrochloric acid $(5 \mathrm{M}, 3.0 \mathrm{~mL})$ was added to a solution of the obtained poly(ether ketone) $(1.50 \mathrm{~g})$ in DMF $(25 \mathrm{~mL})$, and stirred at $80{ }^{\circ} \mathrm{C}$ for $3 \mathrm{~h}$. The reaction mixture was poured into methanol $(250 \mathrm{~mL})$. The precipitated polymer was collected by filtration and dried under vacuum. Yield $92 \%$; white powder; Td $360{ }^{\circ} \mathrm{C}$; Elemental Analysis: $\mathrm{C}_{35} \mathrm{H}_{26} \mathrm{O}_{5}$; Calculated \%C = 79.83, $\% \mathrm{H}=4.98$. Observed $\% \mathrm{C}=79.40, \% \mathrm{H}=4.98$. FT-IR $/$ ATR $v\left(\mathrm{~cm}^{-1}\right): 3600-3200,3060,2930,1650,1600$, 1230, and 1150; ${ }^{1} \mathrm{H}-\mathrm{NMR}$ (DMSO-d ${ }_{6}$ ) ppm: 8.20-7.70 (m, 4H, Ar and -OH), 7.50-7.30 (m, 4H, Ar), 7.30-6.90 (m, 12H, Ar), $3.35\left(\mathrm{~s}, 6 \mathrm{H},-\mathrm{CH}_{3}\right)$.

\subsubsection{Linear Poly(ether ketone) with Methoxy Groups in the Side Chains (Linear-OMe-BisA)}

Compound 5 (0.846 g, $2.5 \mathrm{mmol})$, bisphenol A (0.571 g, $2.5 \mathrm{mmol})$, potassium carbonate $(0.345 \mathrm{~g}$, $2.5 \mathrm{mmol})$, toluene $(10 \mathrm{~mL})$ and DMAc $(20 \mathrm{~mL})$ were stirred in a flask at $120^{\circ} \mathrm{C}$. The temperature was then raised from $120^{\circ} \mathrm{C}$ to $165^{\circ} \mathrm{C}$ to remove water formed during the reaction as an azeotrope in toluene. The reaction mixture was stirred at this temperature for $6 \mathrm{~h}$. The polymerization proceeded homogeneously. After the reaction was completed, the mixture was cooled to room temperature, and poured into water $(300 \mathrm{~mL})$. The precipitated polymer was collected by filtration, and dried under vacuum. Yield 93\%; white powder; Td $370{ }^{\circ} \mathrm{C}$; Elemental Analysis: $\mathrm{C}_{36} \mathrm{H}_{28} \mathrm{O}_{5}$; Calculated $\% \mathrm{C}=79.98$, $\% \mathrm{H}=5.22$. Observed $\% \mathrm{C}=79.65, \% \mathrm{H}=5.05$. FT-IR $/$ ATR $v\left(\mathrm{~cm}^{-1}\right):$ IR(liquid film): 3060, 2930, 1650, 1600, 1230, and $1150 \mathrm{~cm}^{-1}{ }^{1} \mathrm{H}-\mathrm{NMR}$ (DMSO-d ${ }_{6}$ ) ppm: 8.10-7.70 (m, 3H, Ar), 7.50-7.30 (m, 4H, Ar), 7.30-6.96 (m, 12H, Ar), $3.93\left(\mathrm{~s}, 3 \mathrm{H},-\mathrm{OCH}_{3}\right), 3.35\left(\mathrm{~s}, 6 \mathrm{H},-\mathrm{CH}_{3}\right)$.

\section{Conclusions}

1-(tert-Butyldimethylsiloxy)-3,5-bis(4-fluorobenzoyl)benzene was polycondensed with bisphenols, followed by cleavage of the protective group to form linear poly(ether ketone)s, and the properties, such as solubilities, reduced viscosities and thermal properties, were compared with those of poly(ether ether ketone) dendrimer having hydroxyl chain ends and hyperbranched poly(ether ether ketone) having hydroxyl chain ends. A similar comparison was carried out with the corresponding methoxy group polymers. The solubilities of the dendrimers and the hyperbranched polymers were higher than the linear polymers. The reduced viscosities in DMAc of the hyperbranched polymers and the linear polymers increased with the concentrations, but those of the linear polymers increased more significantly. The order of increasing $T_{\mathrm{g}} \mathrm{s}$ was hyperbranched 
polymers $>$ linear polymers $>$ dendrimers, and the hydroxyl linear polymers crystallized thermally. The molecular size was shown to affect their properties.

Acknowledgments: I am thankful for the valuable comments from Katsumichi Ono, emeritus professor at Ibaraki University. I thank Satoshi Kawaguchi and Minoru Akagi for synthesis and characterizations of the compounds.

Author Contributions: Atsushi Morikawa performed synthesis and characterizations of the compounds, and wrote the manuscript.

Conflicts of Interest: The authors declare no conflict of interest.

\section{References}

1. Tomallia, D.A.; Naylor, A.M.; Goddard, W.A. Starburst Dendrimers: Molecular-Level Control of Size, Shape, Surface Chemistry, Topology, and Flexibility from Atoms to Macroscopic Matter. Angew. Chem. Int. Ed. 1990, 29, 138-175. [CrossRef]

2. Hawke, C.J.; Frechet, J.M.J. Control of Surface Functionality in the Synthesis of Dendritic Macromolecules Using the Convergent-Growth Approach. Macromolecules 1990, 23, 4726-4729. [CrossRef]

3. Morikawa, A.; Kakimoto, M.; Imai, Y. Convergent Synthesis of Starburst Poly(ether ketone) Dendrons. Macromolecules 1993, 26, 6324-6329. [CrossRef]

4. Trollsås, M.; Hedrick, J. De drimer-likt Star Polymers. J. Am. Chem. Soc. 1998, 120, 4644-4651. [CrossRef]

5. Morikawa, A.; Ono, K. Preparation of Poly(ether ketone) Dendrons with Graded Structures. Macromolecules 1999, 32, 1062-1068. [CrossRef]

6. Morikawa, A.; Ono, K. Preparation of poly(ether ether ketone) dendrimers by the divergent method. Polym. J. 2000, 32, 234-242. [CrossRef]

7. Morikawa, A.; Ono, K. Preparation of Poly(ether)-(ether ether ketone) Dendrimers by the Convergent Method. Polym. J. 2000, 32, 255-262. [CrossRef]

8. Ishida, Y.; Jikei, M.; Kakimoto, M. Rapid Synthesis of Aromatic Polyamide Dendrimers by an Orthogonal and a Double-Stage Convergent Approach. Macromolecules 2000, 33, 3202-3211. [CrossRef]

9. In, I.; Kim, S.Y. Orthogonal Synthesis of Poly(aryl ether amide) Dendrons. Macromolecules 2005, 38, 9399-9401. [CrossRef]

10. Albrecht, K.; Kasai, Y.; Kimoto, A.; Yamamoto, K. The Synthesis and Properties of Carbazole-Phenylazomethine Double Layer-Type Dendrimers. Macromolecules 2008, 41, 3793-3800. [CrossRef]

11. Van der Poll, D.G.; Kieler-Ferguson, H.M.; Floyd, W.C.; Guillaudeu, S.J.; Jerger, K.; Szoka, F.C.; Fréchet, J.M. Design, Synthesis, and Biological Evaluation of a Robust, Biodegradable Dendrimer. Bioconjugate Chem. 2010, 21, 764-773. [CrossRef] [PubMed]

12. Albrecht, K.; Higashimura, H.; Yamamoto, K. Synthesis and Properties of Nitrogen-Introduced Phenylazomethine Dendrimers. Synth. Commun. 2014, 44, 2239-2247. [CrossRef]

13. Hawker, C.J.; Lee, R.; Frechet, J.M.J. One-pot synthesis of hyperbranched polyesters. J. Am. Chem. Soc. 1991, 113, 4583-4588. [CrossRef]

14. Miller, T.M.; Neenan, T.X.; Kwock, E.W.; Stein, S.M. Dendritic analogs of engineering plastics: A general one-step synthesis of dendritic polyaryl ethers. J. Am. Chem. Soc. 1993, 115, 356-357. [CrossRef]

15. Wooly, K.L.; Frechet, J.M.J.; Hawker, C.J. Influence of shape on the reactivity and properties of dendritic, hyperbranched and linear aromatic polyesters. Polymer 1994, 35, 4489-4495. [CrossRef]

16. Hawker, C.J.; Chu, F. Hyperbranched Poly(ether ketones): Manipulation of Structure and Physical Properties. Macromolecules 1996, 29, 4370-4380. [CrossRef]

17. Jikei, M.; Hu, Z.; Kakimoto, M.; Imai, Y. Synthesis of Hyperbranched Poly(phenylene sulfide) via a Poly(sulfonium cation) Precursor. Macromolecules 1996, 29, 1062-1106. [CrossRef]

18. Morikawa, A. Preparation and Properties of Hyperbranched Poly(ether ketones) with a Various Number of Phenylene Units. Macromolecules 1998, 31, 5999-6009. [CrossRef]

19. Yang, G.; Jikei, M.; Kakimoto, M. Successful Thermal Self-Polycondensation of AB2 Monomer to Form Hyperbranched Aromatic Polyamide. Macromolecules 1998, 31, 5964-5966. [CrossRef]

20. Yamanaka, K.; Jikei, M.; Kakimoto, M. Preparation and Properties of Hyperbranched Aromatic Polyimides via Polyamic Acid Methyl Ester Precursors. Macromolecules 2000, 33, 6937-6944. [CrossRef] 
21. Hao, J.; Jikei, M.; Kakimoto, M. Synthesis and Comparison of Hyperbranched Aromatic Polyimides Having the Same Repeating Unit by AB2 Self-Polymerization and A2 + B3 Polymerization. Macromolecules 2003, 36, 3519-3528. [CrossRef]

22. Li, X.; Li, Y.; Tong, Y.; Shi, L.; Liu, X. Synthesis and Characterization of Hyperbranched Aromatic Poly(ether imide)s. Macromolecules 2003, 36, 5537-5544. [CrossRef]

23. Li, X.; Zhan, J.; Lin, Y.; Li, Y.; Li, Y. Facile Synthesis and Characterization of Aromatic and Semiaromatic Hyperbranched Poly(ester-amide)s. Macromolecules 2005, 38, 8235-8243. [CrossRef]

24. Seino, M.; Hayakawa, T.; Ishida, Y.; Kakimoto, M. Synthesis and Characterization of Crystalline Hyperbranched Polysiloxane with POSS Groups at the Terminal Position. Macromolecules 2006, 39, 8892-8894. [CrossRef]

25. Baek, J.B.; Simko, S.R.; Tan, L.S. Synthesis and Chain-End Modification of a Novel Hyperbranched Polymer Containing Alternating Quinoxaline and Benzoxazole Repeat Units. Macromolecules 2006, 39, 7959-7966. [CrossRef]

26. Xue, Z.; Finke, A.D.; Moore, J.S. Synthesis of Hyperbranched Poly(m-phenylene)s via Suzuki Polycondensation of a Branched AB2 Monomer. Macromolecules 2010, 43, 9277-9282. [CrossRef]

27. Fu, Y.; Vandendriessche, A.; Dehaen, W.; Smet, M. Effective Acid-Catalyzed Synthesis of $100 \%$ Hyperbranched Polyacenaphthenones. Macromolecules 2006, 39, 5183-5186. [CrossRef]

28. Fu, Y.; Oosterwijck, C.W.; Vandendriessche, A.; Kowalczuk-Bleja, A.; Zhang, X.; Dworak, A.; Dehaen, W.; Smet, M. Hyperbranched Poly(arylene oxindole)s with a Degree of Branching of $100 \%$ for the Construction of Nanocontainers by Orthogonal Modification. Macromolecules 2008, 41, 2388-2393. [CrossRef]

29. Jikei, M.; Uchida, D.; Haruta, Y.; Takahashi, Y.; Matsumoto, K. Synthesis and Properties of Hyperbranched Poly(ether sulfone)s Prepared by Self-Polycondensation of Novel AB2 Monomer. J. Polym. Sci. A Polym. Chem. 2012, 50, 3830-3839. [CrossRef]

30. Jikei, M.; Suzuki, M.; Itoh, K.; Matsumoto, K.; Saito, Y.; Kawaguchi, S. Synthesis of Hyperbranched Poly(L-lactide)s by Self-Polycondensation of AB2 Macromonomers and Their Structural Characterization by Light Scattering Measurements. Macromolecules 2012, 45, 8237-8244. [CrossRef]

31. Morikawa, A.; Akagi, M. Hyperbranched poly(ether ether ketone)s: Preparation and comparison of properties the corresponding dendrimers. Polym. J. 2013, 45, 614-621. [CrossRef]

32. Shi, Y.; Nabae, Y.; Hayakawa, T.; Kobayashi, H.; Yabishita, M.; Fukuoka, A.; Kakimoto, M. Synthesis and characterization of hyperbranched aromatic poly(ether ketone)s functionalized with carboxylic acid terminal groups. Polym. J. 2014, 46, 722-727. [CrossRef]

33. Tian, W.; Fan, X.; Kong, J.; Liu, Y.; Hung, Y. Novel supramolecular system of amphiphilic hyperbranched polymer with $\beta$-cyclodextrine and hyperbranched topography cavites: Synthesis and selective encapsulation. Polymer 2010, 51, 2556-2564. [CrossRef]

34. Herrero, M.A.; Guerra, J.; Myers, V.S.; Gómez, M.V.; Crooks, R.M.; Prato, M. Gold Dendrimer Encapsulated Nanoparticles as Labeling Agents for Multiwalled Carbon Nanotubes. ACS Nano 2010, 4, 905-912. [CrossRef] [PubMed]

35. Kaneko, R.; Jikei, M.; Kakimoto, M. Preparation and properties of composite materials composed aromatic polyamides and vinyl polymers. High Perform. Polym. 2002, 14, 41-51. [CrossRef]

36. Gao, H.; Yorifuji, D.; Wakita, J.; Jiang, Z.H.; Ando, S. In situ preparation of nano ZnO/hyperbranched polyimide hybrid film and their optical properties. Polymer 2010, 51, 3173-3180. [CrossRef]

37. Park, B.R.; Nabae, Y.; Surapati, M.; Hayakawa, T.; Kakimoto, M. Poly( $N$-isopropylacrylamide)-modified silica beads with hyperbranched polysiloxane for three-dimensional cell cultivation. Polym. J. 2013, 45, 210-215. [CrossRef]

38. Sudo, Y.; Sakai, H.; Nabae, Y.; Hayakawa, Y.; Kakimoto, M. Preparation of hyperbranched polystyrene-g-poly( $N$-isopropylacrylamide) copolymers and its application to novel thermos-responsible cell culture dishes. Polymer 2015, 70, 307-314. [CrossRef]

39. Kakimoto, M.; Grunzinger, S.J.; Hayakawa, T. Hyperbranched poly(ether sulfone)s: Preparation and application to ion-exchange membranes. Polym. J. 2010, 42, 697-705. [CrossRef]

40. Fang, J.; Kita, H.; Okamoto, K. Hyperbranched Polyimides for Gas Separation Applications. 1. Synthesis and Characterization. Macromolecules 2000, 33, 4639-4646. [CrossRef]

41. Kaneko, R.; Jikei, M.; Kakimoto, M. Preparation and properties of photosensitive polymers based on hyperbranched aromatic polyamides. High Perform. Polym. 2002, 14, 53-62. [CrossRef] 
42. Wang, Y.; Xie, X.; Goodson, T. Enhanced Third-Order Nonlinear Optical Properties in Dendrimer-Metal Nanocomposites. Nano Lett. 2005, 5, 2379-2384. [CrossRef] [PubMed]

43. Xie, J.; Deng, X.; Cao, Z.; Shen, Q.; Zhang, W.; Shi, W. Synthesis and second-order nonlinear optical properties of hyperbranched polymers containing pendant azobenzene chromophores. Polymer 2007, 48, 5988-5993. [CrossRef]

44. Wen, G.A.; Xin, Y.; Zhu, X.R.; Zeng, W.J.; Zhu, R.; Feng, J.C.; Cao, Y.; Zhao, L.; Wang, L.H.; Wei, W.; et al. Hyperbranched triazine-containing polyfluorene: Efficient blue emitters for polymer light-emitting diodes (PLEDs). Polymer 2007, 48, 1824-1829. [CrossRef]

45. Oh, J.H.; Jang, J.; Lee, S.H. Curing behavior of tetrafunctional epoxy resin/hyperbranched polymer system. Polymer 2001, 42, 8339-8347. [CrossRef]

46. Taniguchi, Y.; Shirai, K.; Saitoh, H.; Yamaguchi, T.; Tubokawa, N. Postgrafting of vinyl polymers onto hyperbranched poly(amino-amido)-grafted nano-sized silica surface. Polymer 2005, 46, 2541-2547. [CrossRef]

47. Maruyama, K.; Kudo, H.; Ikehara, T.; Nishikubo, T.; Nishimura, I.; Shishido, A.; Ikeda, T. Synthesis and Properties of Photo-Cross-Linkable Hyperbranched Poly(urethane)s Containing Both Terminal Methacryloyl Groups and Carboxyl Groups. Macromolecules 2007, 40, 4895-4900. [CrossRef]

48. Maity, P.; Yamazoe, S.; Tsukuda, T. Dendrimer-Encapsulated Copper Cluster as a Chemoselective and Regenerable Hydrogenation Catalyst. ACS Catal. 2013, 3, 182-185. [CrossRef]

49. Nabae, Y.; Mikuni, M.; Hayakawa, T.; Kakimoto, M. Synthesis of TEMPO Functionalized Polyimides by A2 + B3 polymerization. J. Photopolym. Sci. Technol. 2014, 27, 139-144. [CrossRef]

50. Nabae, Y.; Liang, J.; Huang, X.; Hayakawa, T.; Kakimoto, M. Sulfonic acid functionalized hyperbranched poly(ether sulfone) as a solid acid catalyst. Green Chem. 2014, 16, 3596-3602. [CrossRef]

51. Shi, Y.; Nabae, Y.; Hayakawa, T.; Kakimoto, M. Hyperbranched aromatic poly(ether ketone) functionalized with TEMPO as heterogeneous catalyst for aerobic oxidation of alkohols. R. Soc. Chem. 2015, 5, 1923-1928.

52. Albrecht, K.; Kasai, Y.; Kuramoto, Y.; Yamamoto, K. A-fouth-generation carbazole-phenylazomethyne dendrimer as a size-sensitive host for fullerenes. Chem. Commun. 2013, 49, 865-867. [CrossRef] [PubMed]

53. Yamamoto, K.; Imaoka, T. Precision Synthesis of Subnanoparticles Using Dendrimers as a Superatom Synthesizer. Acc. Chem. Res. 2014, 47, 1127-1136. [CrossRef] [PubMed]

54. Feng, X.; Taton, D.; Borsali, R.; Chaikof, E.L.; Gnanou, Y. pH Responsiveness of Dendrimer-like Poly(ethylene oxide)s. J. Am. Chem. Soc. 2006, 128, 11551-11562. [CrossRef] [PubMed]

55. Minard-Basquin, C.; Weil, T.; Hohner, A.; Rädler, J.O.; Müllen, K.A. Polyphenylene Dendrimer-Detergent Complex as a Highly Fluorescent Probe for Bioassays. J. Am. Chem. Soc. 2003, 125, 5832-5838. [CrossRef] [PubMed]

56. Nwe, K.; Milenic, D.E.; Ray, G.L.; Kim, Y.S.; Brechbiel, M.W. Preparation of Cystamine Core Dendrimer and Antibody-Dendrimer Conjugates for MRI Angiography. Mol. Pharm. 2012, 9, 374-381. [CrossRef] [PubMed]

57. Albrecht, K.; Matsuoka, K.; Fujita, K.; Yamamoto, K. Carbazole Dendrimers as Solution-Processable Thermally Actived Delayed Fliorescence Materials. Angew. Chem. Int. Ed. 2015, 54, 5677-5682. [CrossRef] [PubMed]

58. Kesharwari, P.; Jain, K.; Jain, N.K. Dendrimer as nanocarrier for drug delivery. Prog. Polym. Sci. 2014, 39, 268-307. [CrossRef]

59. Viswanathan, R.; Johnson, B.C.; McGrath, J.E. Synthesis, kinetic observations and characterizations of polyarylene ether sulphones prepared via a potassium carbonate DMAC process. Polymer 1984, 25, 1827-1836. [CrossRef]

60. Kendal, P.M.; Johson, J.V.; Cook, C.E. Synthetic route to an aromatic analog of strigol. J. Org. Chem. 1979, 44, 1421-1424. [CrossRef]

61. Sinhababu, A.K.; Kawase, M.; Borchardt, R.T. Desilylation of tert-Butyldimethylsilyl Ethers of Phenols. Synthesis 1988, 9, 710-712. [CrossRef]

Sample Availability: Not available.

(c) 2016 by the author; licensee MDPI, Basel, Switzerland. This article is an open access article distributed under the terms and conditions of the Creative Commons by Attribution (CC-BY) license (http://creativecommons.org/licenses/by/4.0/). 